\title{
SIMULASI KEBUTUHAN AIR UNTUK TANAMAN PADI PADA SKENARIO PERUBAHAN IKLIM DI DAERAH ALIRAN SUNGAI LEMBANG-SUMANI
}

\section{SIMULATION OF THE PADDY WATER CROP REQUIREMENT ON CLIMATE CHANGE SCENARIOS IN THE LEMBANG-SUMANI WATERSHED}

\author{
Sugeng Nugroho1,4), Rudi Febriamansyah2), Eri Gas Ekaputra ${ }^{2)}$ Dodo Gunawan ${ }^{3)}$ \\ 1)Mahasiswa Doktoral, Program Studi Ilmu Pertanian, Pascasarjana, Universitas Andalas \\ Kampus Unand Limau Manis, Padang, Sumatera Barat, 25163, Indonesia. \\ 2)Dosen Program Studi Ilmu-Ilmu Pertanian, Pascasarjana, Universitas Andalas. \\ Kampus Unand Limau Manis, Padang, Sumatera Barat, 25163, Indonesia \\ 3)Pusat Informasi Perubahan Iklim BMKG \\ Jln Angkasa I No. 2, Kemayoran, Jakarta Pusat, 10720, Indonesia \\ 4)Stasiun Klimatologi Padang Pariaman, BMKG Sumatera Barat. \\ Jln Padang-Bukittinggi Km.51, Sicincin, Padang Pariaman, Sumatera Barat, 25584, Indonesia. \\ E-Mail: sugeng_ho@yahoo.com
}

Diterima: 1 April 2018; Direvisi: 5 Juli 2018; Disetujui: 22 Februari 2019

\begin{abstract}
ABSTRAK
Dampak perubahan iklim sangat signifikan berpengaruh pada sektor pertanian, mengingat keberlangsungan pertanian bergantung mutlak dengan kondisi iklim. Perubahan iklim yang terjadi pada suatu wilayah sangat tergantung sensitivitas faktor lokal dalam merespon perubahan iklim global yang terjadi, sehingga sangat penting untuk melakukan koreksi data perubahan iklim global dengan data observasi di lokasi. Cumulative Distribution Function based Downscaling Method (CDFDM) merupakan salah satu metode koreksi bias yang dapat digunakan untuk melakukan koreksi tersebut. Kebutuhan air untuk tanaman dan irigasi dihitung dengan model CROPWAT. Hasil analisis menujukkan proyeksi unsur iklim di lokasi penelitian menunjukan pada umumnya mengalami peningkatan. Peningkatan terbesar dialami curah hujan hingga 47,5\% pada tahun 2040 jika iklim berubah dengan skenario RCP8.5 dan rata-rata mengalami peningkatan antara 18-20\% pada tahun 2020-2040, baik pada skenario RCP4.5 dan RCP8.5. Suhu udara akan mengalami peningkatan antara 4-6\% pada tahun 2020-2040 pada skenario RCP4.5 dan RCP8.5. Sedangkan peningkatan suhu udara terbesar per dekade terbesar sekitar $8.1 \%$ pada tahun 2040 pada skenario RCP8.5.Proyeksi kebutuhan air untuk tanaman secara umum mengalami peningkatan seiring dengan semakin tingginya proyeksi curah hujan dan suhu udara, kecuali untuk lokasi penelitian Sumani, yang mengalami defisit kebutuhan curah hujannya sehingga diperlukan air irigasi, pada musim tanam bulan Mei-Agustus.
\end{abstract}

Kata Kunci: CDFDM, CROPWAT, kebutuhan air tanaman , proyeksi perubahan iklim

\section{ABSTRACT}

An impact of climate change is very significant effect on the agricultural sector, because sustainability of agriculture absolutely depends on climate conditions. The climate change that occurs in an area is highly depend on the sensitivity of local factors in responding to global climate change, so it is important to do correction of global climate change data with on-site observation data. CDFDM is one of the bias correction methods that can be used to make such corrections. Water requirements for crops and irrigation are calculated using the CROPWAT model. The results of the analysis showed that the projection of climate element in the research location shows that in general has increased. The greatest increase in rainfall is up to $47.5 \%$ by 2040 if the climate changes with the RCP8.5 scenario and the average increases between $18-20 \%$ in 2020-2040, both on scenes RCP4.5 and RCP8.5. Air temperature will increase between 4-6\% in 2020-2040 on scenario RCP4.5 and RCP8.5. The largest increase in air temperature per decade was $8.1 \%$ by 2040 on the RCP8.5 scenario. The projection of water demand for crops in general has increased in line with the higher rainfall and air temperature projections, except for Sumani study sites, which experienced a deficit in rainfall requirements, which required irrigation water, in the May-August planting season.

Keywords: CDFDM, CROPWAT, crop water requirement, projection of climate change 


\section{PENDAHULUAN}

Kebutuhan pangan akan terus meningkat seiring dengan pertumbuhan jumlah penduduk di suatu daerah. Untuk itu pengelolaan ketersediaan pangan menjadi suatu hal yang sangat penting, terutama pengelolaan pasokan akan bahan pangan itu sendiri. Sektor pertanian merupakan pemasok utama bahan pangan bagi mayoritas penduduk di Indonesia. Sehingga pemerintah mengadakan program swasembada pangan demi menjaga ketersediaan bahan pangan, khususnya padi (beras).

Seiring dengan berjalannya waktu dan tuntutan akan kebutuhan pangan, arah pembangunan pertanian telah mengalami perubahan, yang semula untuk menjaga kelestarian swasembada pangan, khususnya padi (beras), ke pertanian yang berorientasi pada sistem usaha tani agroindustri. Sistem usaha tani agro industri sangat dipengaruhi oleh ketersediaan air bagi kebutuhan pertumbuhan tanaman. Ketidakpastian ketersediaan air hujan di kawasan Indonesia yang beriklim muson tropis basah, dapat diatasi dengan sistem irigasi yang memiliki nilai kepastian, baik dalam jumlah, waktu maupun ruang dalam setiap proses produksi tanaman. Ketersediaan air dalam system irigasi memerlukan peningkatan kemampuan daerah aliran sungai (DAS) untuk dapat menyimpan dan mengendalikan ketersediaan air pada suatu DAS sebagai sumber air utama pada system irigasi (Ekaputra, 2007). Ketersediaan air irigasi sangat tergantung dari debit aliran sungai. Selain dipengaruhi oleh kesehatan dari suatu DAS, debit aliran sungai juga sangat dipengaruhi oleh iklim. Terjadinya perubahan iklim akan mempengaruhi pola hujan dalam sekala volume, ruang dan waktu, yang pada akhirnya akan berdampak terhadap aliran sungai. Perubahan iklim berdampak terhadap penurunan total debit tahunan sungai (Suprapto, 2012).

Penelitian tentang analisis iklim ekstrim di wilayah Sumatera Barat menunjukan secara umum telah terjadi kenaikan suhu udara dan terdapat kecenderungan peningkatan curah hujan ekstrim di wilayah dataran tinggi, dan mengalami trend negatif di wilayah dataran rendah. Hasil analisis juga menunjukan terjadinya pergeseran pola suhu sebesar $0.5^{\circ} \mathrm{C}$ hingga $1.0^{\circ} \mathrm{C}$ baik di daerah dataran rendah maupun tinggi, dan pergeseran pola hujan, yaitu terjadinya pergeseran pola hujan menjadi lebih rendah di daerah dataran rendah dan kecenderungan terjadinya peningkatan jumlah curah hujan di daerah dataran tinggi. Berdasarkan hasil uji trend dapat diketahui perubahan iklim direspon lebih baik oleh perubahan suhu udara dibandingkan dengan perubahan curah hujan, baik di wilayah dataran tinggi maupun dataran rendah di wilayah Sumatera Barat (Nugroho, dkk., 2017).

Kawasan Danau Singkarak terletak di dua kabupaten, yaitu Kabupaten Solok dan Tanah Datar, merupakan daerah lumbung padi untuk Provinsi Sumatera Barat, bahkan untuk tingkat nasional dengan brand beras yang sangat terkenal, yaitu beras solok. Daerah Tangkapan Air Danau Singkarak terdiri dari tiga DAS yang sungainya mengalir ke danau tersebut, yaitu DAS Sumani, DAS Singkarak dan DAS Sumpur. DAS Sumani terdiri dari sungai Lembang dan sungai Sumani, sehingga juga sering disebut DAS Lembang Sumani yang secara administrasi terletak di Kabupaten Solok dan Kota Solok, Provinsi Sumatera Barat mempunyai luas areal sekitar 583,30 $\mathrm{km}^{2}$. Ditinjau dari kesehatan biofisiknya, DAS Sumani merupakan daerah yang kondisinya paling buruk, dimana sungai Lembang dan Sumani yang melintas di DAS tersebut mengalami penurunan debit dan permasalahan kualitas air karena tingginya sedimentasi (Mizwar, 2012).

Menurut Ekaputra (2007), permasalahan penggunaan air di kawasan DAS Lembang Sumani yang masih relevan hingga saat ini diantaranya adalah terjadinya kompetisi penggunaan air antara sektor pertanian dan sektor domestic maupun non-domestik. Penggunaan air untuk sector pertanian terutama untuk sawah beririgasi merupakan pengguna air terbanyak yang akan terus meningkat penggunaannya seiring dengan peningkatan intensitas tanam karena menggunakan bibit padi berumur pendek yang didorong oleh tuntutan pasar akan kebutuhan pangan yang terus meningkat. Kebutuhan air domestik dan non-domestik juga terus meningkat seiring dengan laju pertumbuhan penduduk dan meningkatnya pembangunan di kawasan DAS Lembang Sumani, seperti kebutuhan air untuk air bersih untuk rumah tangga, sekolah, gedung perkantoran, industri, tempat ibadah bahkan untuk tempat pencucian mobil. Kompetisi penggunaan air tersebut akan semakin sengit terjadi manakala sumber air (air permukaan dan mata air), di kawasan tersebut relative tetap, sedangkan kebutuhan terhadap air semakin meningkat.

Keberadaan dan fluktuasi sumber air setidaknya dipengaruhi oleh dua komponen utama, yaitu iklim dan lingkungan.Faktor iklim yang berpengaruh terhadap sumber air, mempunyai dimensi ruang interaksi yang luas, sehingga faktor perubahan iklim yang bersifat 
global dapat mempengaruhi sumber air di suatu kawasan DAS, yang pengaruhnya tergantung sensitivitas faktor lokal dalam merespon perubahan iklim global yang terjadi, yaitu tergantung dari sensitivitas suatu lingkungan dalam merespon perubahan iklim. Lingkungan yang dimaksud dapat berupa pola iklim di suatu wilayah, sistem hidrologi di dalam DAS, atau sistem pertumbuhan tanaman pada suatu lahan pertanian dalam merespon perubahan iklim. Sehingga dampak perubahan iklim yang terjadi bersifat global, akan dirasakan bervariasi secara lokal, baik dalam sekala ruang maupun waktu (Withanachchi, dkk., 2014; Zhang, dkk., 2016). Sedangkan faktor lingkungan yang mempengaruhi sumber air mempunyai dimensi ruang interaksi yang sempit, seperti misalnya berkurangnya wilayah resapan air atau menurunya kualitas biofisik DAS yang menyebabkan menurunnya fungsi-fungsi hidrologi DAS dalam mengendalikan aliran air sungai. Dalam kasus DAS Lembang Sumani, faktor lingkungan yang paling mengkhawatirkan adalah semakin luasnya lahan kritis sebagai akibat dari alih fungsi lahan hutan menjadi non hutan, seperti rusaknya wilayah resapan air di kawasan hulu DAS lembang Sumani, yang beralih fungsi menjadi lahan-lahan pertanian tanaman semusim dan pengembangan kawasan wisata beserta aksesibilitasnya. Kepindahan ibu kota Kabupaten Solok dari Kota Solok ke Arosuka yang berada di kawasan hulu dari DAS ini akan berakibat pada kerusakan kawasan tangkapan dan resapan air DAS Lembang Sumani (Saidi, 1995; Ekaputra, 2007; Nugroho, 2010).

Berdasarkan latar belakang yang telah diuraikan, maka tujuan dari penelitian ini adalah untuk mengetahui pengaruh perubahan iklim terhadap kebutuhan air untuk tanaman dan irigasi di kawasan DAS Lembang Sumani dengan menggunakan data proyeksi perubahan iklim.

\section{METODOLOGI}

Lokasi penelitian berada di kawasan DAS Lembang Sumani. Berdasarkan karakteristik iklimnya wilayah penelitian diambil empat sampel lokasi, yaitu sampel A untuk lokasi di Sukarami, sampel B untuk lokasi di sekitar Muara Panas, sampel C untuk lokasi di Lubuk Sikarah dan sampel D untuk lokasi di sekitar Sumani. Selain karena pola iklimnya, sampel lokasi tersebut diharapkan dapat merepresentasikan DAS Lembang Sumani secara keseluruhan. Selain itu lokasi-lokasi yang dijadikan sampel rata-rata juga mempunyai daerah irigasi yang luas sehingga kedepan, penelitian lanjutan dapat menghubungkan perubahan iklim terhadap kebutuhan air irigasi untuk pertanian. Peta dan diskripsi lebih detil lokasi peneitian seperti disajikan pada Gambar 1 dan Tabel 1.

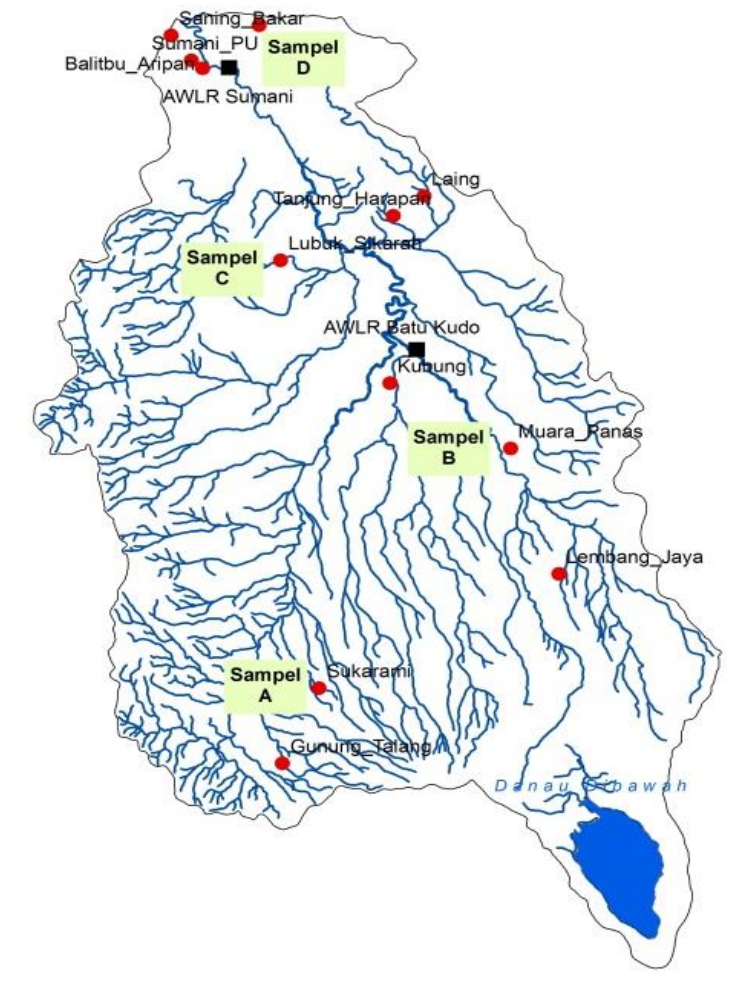

Gambar 1 Peta lokasi wilayah penelitian

Tabel 1 Diskripsi lokasi penelitian

\begin{tabular}{|c|c|c|c|}
\hline \multirow{2}{*}{$\begin{array}{l}\text { Sampel Wilayah } \\
\text { Penelitian }\end{array}$} & \multicolumn{3}{|c|}{ Luas Irigasi (Ha) } \\
\hline & Teknis & $\begin{array}{l}\text { Semi } \\
\text { Teknis }\end{array}$ & $\begin{array}{l}\text { Non- } \\
\text { Teknis }\end{array}$ \\
\hline A. Sukarami & 608 & 1673 & 1090 \\
\hline B. Muara Panas & 1730 & 0 & 596 \\
\hline C. Lubuk Sikarah & 560 & 0 & 0 \\
\hline D. Sumani & 650 & 392 & 655 \\
\hline
\end{tabular}

sumber: BPS Kota Solok dan Kabupaten Solok 2016

\section{1) Data}

Data yang akan digunakan dalam penelitian ini terbagi ke dalam dua kelompok besar, yaitu data iklim hasil observasi dan data model proyeksi perubahan iklim, yang terdiri dari unsur iklim yaitu curah hujan, suhu udara maksimum, suhu udara minimum dan data penguapan dalam resolusi waktu harian. Data observasi yang digunakan dalam penelitian ini merupakan data observasi reanalisis atau data observasi hasil keluaran sebuah model. Untuk data curah hujan digunakan data Climate Hazards Group InfraRed Precipitation with Station Data (CHIRPS) yang 
pada awalnya dikembangkan untuk memenuhi kebutuhan data curah hujan dengan resolusi tinggi untuk memberikan peringatan dini akan bahaya kelaparan (famine) oleh United States Agency for International Development Famine Early Warning Systems Network (FEWS NET). Versi terakhir dari data tersebut mempunyai resolusi spasial $0.05^{\circ} \times 0.05^{\circ}$ yang dapat diakses pada ftp://chgftpout.geog.ucsb.edu/pub/org/chg/products/CHI RPS-2.0/. Sedangkan data suhu udara maksimum dan minimum menggunakan data dari European Centre for Medium-Range Weather Forecasts (ECMWF) yang dapat diakses padalaman http://apps.ecmwf.int/datasets/data/interimfull-daily/levtype=sfc/. ECMWF merupakan data reanalisis dari hasil pemrosesan model dan asimilasi (numerical weather prediction) data satelit serta data pengamatan insitu.Data ECMWF mempunyai resolusi spasial $0.25^{\circ} \mathrm{x} 0.25^{\circ}$. Penelitian ini akan menggunakan data observasi dari kedua model tersebut selama periode tahun 1981-2015.

Untuk mengetahui perubahan iklim, digunakan data proyeksi iklim yang akan datang hasil pemodelan data iklim secara global (Global Circulation Models/GCMs). Model data GCMs yang digunakan dalam penelitian ini model MRICGCM3, MIROC-ESM, MIROC-ESM-CHEM, MPIESM-LR, dan MPI-ESM-MR dengan menggunakan skenario perubahan iklim RCP4.5 dan RCP8.5. Representative Concentration Pathways (RCPs) merupakan skenario perubahan iklim menggunakan tingkat perubahan iklim berdasar tingkat radiative forcing ( $\mathrm{RF}$ ) di atmosfer dengan mempertimbangkan kondisi iklim saat ini. RCP4.5 dan RCP8.5 masing-masing mempunyai arti skenario perubahan iklim dengan tingakat $\mathrm{RF}$ yang terjadi di atmosfer sebesar $4,5 \mathrm{~W} / \mathrm{m}^{2}$ dan $8,5 \mathrm{~W} / \mathrm{m}^{2}$ pada tahun 2100 relatif terhadap nilai pada saat pra-industri (Weyant, dkk., 2009). Data-data tersebut berformat grid netCDF dengan resolusi waktu harian dan resolusi spasial $0.25^{\circ} \times 0.25^{\circ}$, dengan periode tahun 1950-2005 (historical) dan 2006-2040 (RCP4.5 / RCP8.5). Data model GCMs dapat diakses melalui laman ftp.nccs.nasa.gov. Diskripsi dari masing-masing model seperti terlihat pada Tabel 2.

Tabel 2. Diskripsi Data Model Perubahan Iklim

\begin{tabular}{|c|c|c|}
\hline \multirow{2}{*}{ Nama Model } & \multicolumn{2}{|c|}{ Pengembang } \\
\hline & Institusi & Negara \\
\hline MRI-CGCM3 & $\begin{array}{l}\text { Meteorological } \\
\text { Research Institute }\end{array}$ & Jepang \\
\hline MIROC-ESM & $\begin{array}{l}\text { JAMSTEC-University } \\
\text { of Tokyo-NIES }\end{array}$ & Jepang \\
\hline $\begin{array}{l}\text { MIROC-ESM- } \\
\text { CHEM }\end{array}$ & $\begin{array}{l}\text { JAMSTEC-University } \\
\text { of Tokyo-NIES }\end{array}$ & Jepang \\
\hline
\end{tabular}

\begin{tabular}{l|l|c}
\hline MPI-ESM-LR & $\begin{array}{l}\text { Max Planck Intitute } \\
\text { for Meteorology }\end{array}$ & Jerman \\
\hline MPI-ESM-MR & $\begin{array}{l}\text { Max Planck Intitute } \\
\text { for Meteorology }\end{array}$ & Jerman \\
\hline
\end{tabular}

2) Pengolahan Data

Data-data iklim pada masing-masing lokasi (Tabel 1) ditentukan dengan melakukan prosesdownscaling. Statistic downscaling dilakukan terhadap data iklim dari masingmasing data model perubahan iklim yang digunakan dalam penelitian ini (Tabel 2), seperti yang diilustrasikan pada Gambar 2. Koreksi perlu dilakukan karena data GCMs mempunyai tingat kekasaran yang relative tinggi, terutama dalam sekala ruang. Dalam penelitian ini koreksi terhadap data model perubahan iklim GCMs dengan menggunkan metode koresi bias, yaitu Cumulative Distribution Function based Downscaling Method (CDFDM). (Iizumi, dkk., 2011; Iizumi, dkk., 2017). Worksheet program CDFDM telah dibuat untuk mempermudah penggunaan metode koreksi bias tersebut (Tonouchi dan Chiba, 2015).

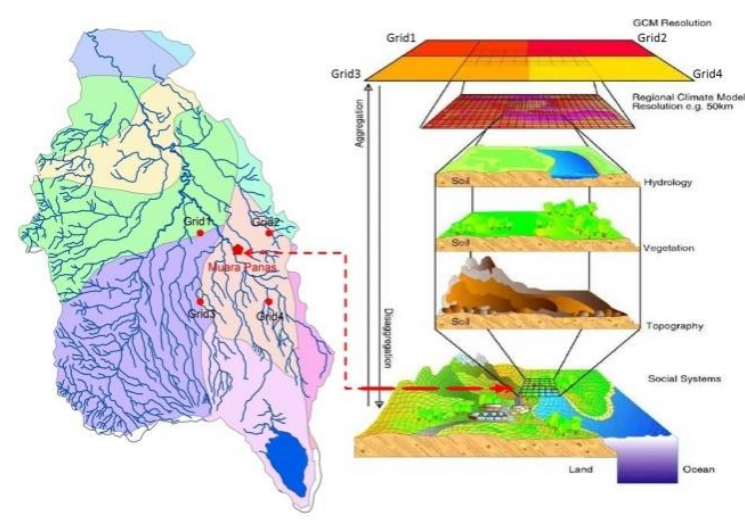

Gambar 3 llustrasi proses downscaling

Kebutuhan air untuk tanaman air (Crop water requirements/CWR) dan kebutuhan untuk irigasi (Irrigation requirements/Irr.Req) untuk masing-masing lokasi penelitian akan dihitung dengan menggunakan model CROPWAT. CROPWAT merupakan sebuah software dicision support system yang dikembangkan oleh Land and Water Development Division, Food and Agriculture Organization (FAO). CROPWAT menghitung kebutuhan air untuk tanaman berdasarkan laju evapotraspirasi standard berdasarkan model Penmann-Monteith (Monteith, 1965; Clarke, dkk., 1998). Beberapa penelitian menunjukan bahwa perhitungan kebutuhan air untuk tanaman berdasarkan pada evapotranspirasi model Penmann-Monteith 
mempunyai tingkat keakuratan yang baik (Kuo, dkk., 2001; Doria, 2010; Surendran, dkk., 2017). Pada penelitian ini akan digunakan CROPWAT for Windows versi 8.0.

Data input model CROPWAT dibuat dengan asumsi penanaman padi sepanjang tahun. Data evapotranspirasi dihitung dengan model Panmann-Monteith berdasarkan data suhu udara maksimum dan minimum.Curah hujan efektif diskenariokan sebesar 80\% dari besarnya curah hujan yang terjadi. Kebutuhan air untuk tanaman dihitung dengan persamaan:

$$
\mathrm{CWR}=\mathrm{Kc} \times \mathrm{ETo}
$$

dimana :

CWR = kebutuhan air tanaman (mm/hari)

$\mathrm{Kc}=$ koefisien tanaman

ETo $=$ potensial evapotranspirasi $(\mathrm{mm} / \mathrm{hari})$

Sedangkan kebutuhan air untuk irigasi dihitung berdasarkan persamaan:

$$
\text { Irr.Req. = CWR-Eff. Rain }
$$

dimana:

Irr.Req = kebutuhan air untuk irigasi (mm/hari)

CWR = kebutuhan air tanaman (mm/hari)

Eff. Rain = curah hujan efektif $(\mathrm{mm})$

$$
\text { Eff.Rain }=0.8 x \text { PRtot }
$$

dimana:

Eff. Rain = curah hujan efektif $(\mathrm{mm})$

PRtot = total jumlah curah hujan (mm)

Diskripsi dapa input model CROPWAT seperti terlihat pada Tabel 3.

Analisis dampak perubahan iklim terhadap kebutuhan air tanaman dan kebutuhan air irigasi dilakukan dengan melakukan perbandingan, antara data hasil proyeksi tahun 2020-2040 dibandingkan dengan data baseline periode 1981-2015, periode data yang dianggap merepresentasikan data hasil observasi, dengan menggunakan persamaan matematis sederhana berikut:

$$
X_{\text {perubahan }}=\frac{X_{\text {proyeksi }}-X_{\text {baseline }}}{X_{\text {baseline }}} \times 100 \%
$$

\section{PEMBAHASAN}

Perubahan dan proyeksi iklim di wilayah penelitian

Data-data perubahan iklim yang merupakan data GCMs, dibangun dengan menggunakan asumsi parameter-parameter atmosfer secara global, sehingga faktor-faktor lokal yang juga menentukan kondisi iklim setempat tidak diikutkan dalam proses tersebut. Hal demikian menyebabkan terjadinya penyimpangan antara data GCMs yang bersekala global dengan data observasi pada sekala lokal. Untuk itu perlu dilakukan koreksi terhadap data GCMs tersebut. Walaupun demikian, nilai data GCMs yang telah dikoreksi tidak akan pernah sama persis dengan data observasi. Terdapat kemungkinan pada awalnya data GCMs cenderung mempunyai nilai yang lebih rendah (under estimate) dan mempunyai nilai variasi yang cenderung sama (tingkat variasi rendah), sehingga tidak mampu menangkap nilai-nilai batas bawah dan atas dari suatu unsur iklim, seperti curah hujan yang cenderung mempunyai tingkat variasi yang tinggi. Sedangkan nilai data GCMs yang telah dikoreksi sudah terlihat mempunyai tingkat variasi yang tinggi dan mempunyai kemiripan pola dengan data observasi walaupun nilainya tidak sama. Pada unsur iklim suhu udara, data GCMs juga under estimate dari data observasi walaupun mempunyai pola dan variasi yang lebih baik dibandingkan dengan data curah hujan. Nilai data GCM yang telah dikoreksi juga tampak mempunyai tingkat kesamaan pola yang lebih baik dibandingkan data hujan.

Pada sekala lokal Sumatera Barat, juga jelas terlihat perbedaan kenaikan curah hujan, suhu maksimum dan minimum untuk di wilayah dataran tinggi dan dataran rendah. Dari kelima model GCMs yang digunakan, hampir semuanya menunjukan kenaikan curah hujan di wilayah dataran rendah lebing tinggi dibandingkan kenaikan curah hujan di wilayah dataran tinggi. Kondisi tersebut berkebalikan dengan suhu udara maksimum dan minimum, dimana persentase kenaikan suhu udara maksimum ataupun minimum lebih besar di wilayah dataran tinggi dibandingkan di wilayah dataran rendah (Nugroho, dkk., 2017).

Dilihat dari performa model GCMs yang digunakan terlihat, secara umum bahwa model MPI-ESM-LR dan MPI-ESM-MR mempunyai performa yang bagus untuk data curah hujan dan suhu udara minimum terlihat dari nilai bias model tersebut yang lebih kecil dibandingkan model lainnya. Sedangkan untuk data maksimum, 
selain kedua model terbaik tersebut, model MIROC-ESM dan MIROC-ESM-CHEM juga mempunyai tingkat performa yang hampir sama. Ghahreman, dkk., (2015) dalam penelitiannya untuk investigasi ketidakpastian data hasil proyeksi suhu udara dan curah hujan dengan menggunkan model GCMs luaran IPCC AR5 di wilayah Iran juga menyimpulkan bahwa model MPI-ESM-LR, MPI-ESM-MR dan NorEMS1-M, merupakan model-model terbaik dalam proyeksi data iklim.

Tabel 3 Skenario Inputan Data pada Model CROPWAT

\begin{tabular}{|c|c|c|c|c|c|}
\hline \multirow{2}{*}{$\begin{array}{l}\text { Variabel } \\
\text { Input }\end{array}$} & \multicolumn{3}{|c|}{ Curah Hujan } & \multicolumn{2}{|r|}{ Suhu Udara Maks \& Min } \\
\hline & Periode & & Sumber Data & Periode & Sumber Data \\
\hline \multirow[b]{2}{*}{ Iklim } & $\begin{array}{c}\text { Observasi } \\
(1981-2015) \\
\end{array}$ & & CHIRPS & $\begin{array}{c}\text { Observasi } \\
(1981-2015) \\
\end{array}$ & ECMWF \\
\hline & $\begin{array}{c}\text { Proyeksi } \\
(2020-2040)\end{array}$ & & $\begin{array}{l}\text { el } 5 \text { Model Perubahan } \\
\text { engan skenario RCP4.5 } \\
\text { dan RCP8.5 }\end{array}$ & $\begin{array}{c}\text { Proyeksi } \\
(2020-2040)\end{array}$ & $\begin{array}{l}\text { Ensembel } 5 \text { Model Perubahan Iklim } \\
\text { dengan skenario RCP4.5 dan RCP8.5 }\end{array}$ \\
\hline \multirow[b]{2}{*}{ Tanaman } & Jenis Tanaman & \multicolumn{3}{|c|}{ Periode Tanam (120 hari/musim) } & Sumber Data \\
\hline & Padi (rice) & \multicolumn{3}{|c|}{$\begin{array}{l}\text { Musim Tanam } 1(01 / 01-30 / 04) \\
\text { Musim Tanam } 1(01 / 05-29 / 08) \\
\text { Musim Tanam } 1(01 / 09-26 / 12)\end{array}$} & CROPWAT/FAO \\
\hline \multirow[b]{2}{*}{ Tanah } & \multicolumn{2}{|c|}{ Lokasi } & \multicolumn{2}{|l|}{ Jenis Tanah } & Sumber Data \\
\hline & \multicolumn{2}{|c|}{$\begin{array}{c}\text { Sukarami } \\
\text { Muara Panas } \\
\text { Lubuk Sikarah } \\
\text { Sumani }\end{array}$} & $\begin{array}{l}\text { Liat berpasir } \\
\text { Liat berpasir } \\
\text { Liat berpasir } \\
\text { Liat berpasir }\end{array}$ & & Saidi, 1995 \\
\hline
\end{tabular}

Hasil koreksi bias dengan metode CDFDM menunjukkan bahwa metode tersebut tidak menujukkan performa yang bagus untuk mengoreksi hujan. Hal ini terlihat dari nilai bias, MAE dan RMSE data hujan sebelum dan setelah dilakukan koreksi bias (CDFDM), dimana hasil setelah dilakukan koreksi mempunyai nilai bias, MAE dan RMSE yang lebih besar dibandingkan dengan data sebelum dikoreksi, baik untuk di wilayah dataran tinggi maupun di wilayah dataran rendah. Hasil kajian Iizumi, dkk., (2011) yang juga menggunakan CDFDM untuk mengoreksi data model dari empat regional climate models (NHRCM, NRAMS, TRAMS, dan TWRF) di Jepang menggunakan data curah hujan harian pada periode 1985 - 2004, juga menunjukan metode CDFDM tidak begitu bagus dalam mengoreksi curah hujan ekstrim. Namun Muharsyah (2018), menyimpulkan bahwa koreksi bias dengan metode CDFDM dapat memberikan peningkatan akurasi (jumlah stasiun yang sesuai dengan data observasi) dibandingkan dengan data model sebelum dikoreksi berdasarkan empat indikasi : Mean daily precipitation (MEA), Intensity of precipitation (INT), Fraction of Wet days (FRE) dan Percentile90 (Q90) terutama pada periode JJA (kering) dengan curah hujan sebesar rata-rata kurang dari $15 \mathrm{~mm} /$ hari. Koreksi bias metode CDFDM menunjukan performa yang lebih bagus dalam koreksi bias suhu udara maksimum dan minimum dibandingkan koreksi bias untuk curah hujan baik itu di wilayah dataran tinggi maupun di dataran rendah terlihat dari nilai bias, MAE dan RMSE yang lebih kecil setelah dikoreksi CDFDM walaupun tidak semua model menunjukan hal tersebut. Perlu ditekankan bahwa CDFDM dapat memperkecil nilai bias untuk data suhu udara maksimum dan minimu tetapi nilai MAE dan RMSE nya tidak mengalami penurunan nilai secara signifikan setelah dilakukan koreksi, bahkan ada beberapa model yang tidak mengalami perubahan nilai

Nilai tingkat kesamaan data observasidan data GCMs yang telah dikoreksi, salah satunya dapat dilihat dari tingkat keeratan hubungan (korelasi) antara kedua nilai data tersebut. Pada Tabel 5a, terlihat nilai korelasi data observasi dan data $\mathrm{gcm}$, selain ditentukan oleh unsur iklim juga oleh faktor lokal (lokasi). Nilai koefisien korelasi curah hujan mempunyai nilai korelasi sebesar 0,2 hingga 0,3. Suhu udara maksimum/minimum mempunyai nilai korelasi sebesar 0,5 hingga 0,6. Sementara koefisien korelasi berdasarkan lokasi, terlihat secara umum di lokasi Lubuk Sikarah mempunyai nilai hubungan data obs dan data GCMs lebih baik dibandingkan lokasi lainnya. Seperti telah dikemukakan sebelumnya, bahwa curah hujan mempunyai nilai keeratan yang lebih rendah dibandingkan data suhu udara hasil 
model jika dibandingkan data observasinya. Sedangkan fakor lokal dalam hal ini lokasi, dimana masing-masing lokasi mempunyai sensitivitas yang berbeda dalam merespon data GCMs yang bersekala global tersebut. Perbandingan data proyeksi terhadap baselinenya digunakan untuk melihat seberapa besar perubahan unsur-unsur iklim yang terjadi di lokasi-lokasi penelitian akibat perubahan iklim. Untuk itu akan dibandingkan proyeksi dengan skenario RCP4.5 dan RCP8.5 terhadap data baselinenya. Skenario RCP4.5 yang bersekala menengah akan memberikan pengaruh perubahan yang lebih rendah dibandingkan RCP8.5 yang diskenariokan mempunyai sekala perubahan yang lebih tinggi.

Seperti yang terlihat pada Tabel $4 b$, prosentase perubahan proyeksi curah hujan ratarata tahun 2020-2040 berkisar antara 18-20\% dibandingkan baseline. Nilai perubahan terbesar terjadi di Lubuk Sikarah sebesar $21,6 \%$ pada skenario RCP4.5 dan terendah sebesar 18,3\% terjadi di Muara Panas pada skenario RCP8.5. Untuk proyeksi per dekade, prosentase perubahan curah hujan terbesar terjadi di Lubuk Sikarah sebesar $47,5 \%$ pada tahun 2040 dengan scenario RCP8.5. Sementara prosentase perubahan terendah sebesar $10 \%$ terjadi juga di Lubuk Sikarah pada tahun 2020 dengan skenario perubahan RCP4.5.
Prosentase perubahan proyeksi suhu udara maksimum rata-rata tahun 2020-2040 berkisar antara 4-6\% dibandingkan baseline (Tabel 4c). Nilai perubahan terbesar terjadi di Sumani sebesar 6,2\% pada skenario RCP8.5 dan terendah sebesar 4,6\% terjadi di Lubuk Sikarah, Muara Panas dan Sukarami pada skenario RCP4.5. Untuk proyeksi per dekade, prosentase perubahan suhu udara terbesar terjadi di Sumani dan Sukarami, dengan perubahan masing-masing sebesar $8.0 \%$ pada tahun 2030 dengan skenario RCP8.5. Sementara prosentase perubahan terendah sebesar 2,8\% terjadi juga di Lubuk Sikarah, Muara Panas dan Sukarami pada tahun 2020 dengan skenario prubahan RCP8.5.

Prosentase perubahan proyeksi suhu udara minimum rata-rata tahun 2020-2040 berkisar antara 4-6\% dibandingkan baseline. Nilai perubahan terbesar terjadi di Sukarami sebesar $5,9 \%$ baik pada pada scenario RCP4.5 maupun RCP8.5 dan terendah sebesar 4,9\% terjadi di Lubuk Sikarah dan Muara Panas pada scenario RCP4.5. Untuk proyeksi per dekade, prosentase perubahan suhu udara terbesar terjadi di Sumani dan Sukarami, dengan perubahan masing-masing sebesar $8,1 \%$ pada tahun 2040 dengan skenario RCP8.5. Sementara prosentase perubahan terendah sebesar $1,9 \%$ terjadi juga di Lubuk Sikarah dan Muara Panas pada tahun 2020 dengan skenario prubahan RCP8.5 (Tabel 4d).

Tabel 4a Koefisien Korelasi antara Data Iklim Observasi dan Data Model Perubahan Iklim (GCMs)

\begin{tabular}{l|l|l|l|l|l|l|l|l}
\hline \multirow{2}{*}{ Unsur Iklim } & \multicolumn{2}{|c|}{ Sumani } & \multicolumn{2}{c|}{ Lubuk Sikarah } & \multicolumn{2}{c|}{ Muara Panas } & \multicolumn{2}{c}{ Sukarami } \\
\cline { 2 - 9 } & RCP4.5 & RCP8.5 & RCP4.5 & RCP8.5 & RCP4.5 & RCP8.5 & RCP4.5 & RCP8.5 \\
\hline Curah Hujan & 0,27 & 0,24 & 0,30 & 0,27 & 0,28 & 0,22 & 0,27 & 0,23 \\
\hline Suhu Udara Minimum & 0,56 & 0,57 & 0,55 & 0,57 & 0,55 & 0,57 & 0,50 & 0,52 \\
\hline Suhu Udara Maksimum & 0,58 & 0,57 & 0,59 & 0,60 & 0,59 & 0,5 & 0,58 & 0,58 \\
\hline
\end{tabular}

Tabel 4b Perbandingan curah hujan Proyeksi terhadap baseline di lokasi penelitian (\%)

\begin{tabular}{|c|c|c|c|c|c|c|c|c|}
\hline \multirow{2}{*}{$\begin{array}{l}\text { Periode } \\
\text { Proyeksi }\end{array}$} & \multicolumn{2}{|c|}{ Sumani } & \multicolumn{2}{|c|}{ Lubuk Sikarah } & \multicolumn{2}{|c|}{ Muara Panas } & \multicolumn{2}{|c|}{ Sukarami } \\
\hline & $\mathrm{RCP} 4.5$ & $\mathrm{RCP} 8.5$ & $\mathrm{RCP} 4.5$ & $\mathrm{RCP} 8.5$ & $\mathrm{RCP} 4.5$ & RCP8.5 & $\mathrm{RCP} 4.5$ & RCP8.5 \\
\hline Thn 2020 & 11,5 & 30,7 & 10,0 & 27,5 & 10,1 & 25,6 & 10,2 & 27,6 \\
\hline Thn 2030 & 36,6 & 28,2 & 38,2 & 31,5 & 36,4 & 30,2 & 38,3 & 31,7 \\
\hline Thn 2040 & 20,3 & 45,7 & 17,6 & 47,5 & 15,4 & 45,6 & 17,6 & 47,7 \\
\hline Rata-rata 2020-2040 & 21,2 & 19,5 & 21,6 & 19,3 & 20,5 & 18,3 & 21,7 & 19,3 \\
\hline
\end{tabular}


Jurnal Sumber Daya Air Vol. 15 No 1, Mei 2019: 15 - 26

Tabel 4c Perbandingan suhu udara maksimum proyeksi terhadap baseline di lokasi penelitian (\%)

\begin{tabular}{l|l|l|l|l|l|l|l|l}
\hline \multirow{2}{*}{$\begin{array}{l}\text { Periode } \\
\text { Proyeksi }\end{array}$} & \multicolumn{2}{|c|}{ Sumani } & \multicolumn{2}{c|}{ Lubuk Sikarah } & \multicolumn{2}{c}{ Muara Panas } & \multicolumn{2}{c}{ Sukarami } \\
\cline { 2 - 9 } & RCP4.5 & RCP8.5 & RCP4.5 & RCP8.5 & RCP4.5 & RCP8.5 & RCP4.5 & RCP8.5 \\
\hline Thn 2020 & 4,4 & 3,2 & 3,5 & 2,8 & 3,5 & 2,8 & 3,5 & 2,8 \\
\hline Thn 2030 & 4,2 & 8,0 & 4,2 & 7,8 & 4,2 & 7,9 & 4,2 & 8,0 \\
\hline Thn 2040 & 7,8 & 7,3 & 7,6 & 7,1 & 7,7 & 7,1 & 7,7 & 7,1 \\
\hline Rata-rata 2020-2040 & 4,9 & 6,2 & 4,6 & 5,9 & 4,6 & 6,0 & 4,6 & 6,0 \\
\hline
\end{tabular}

Tabel 4d Perbandingan suhu udara minimum proyeksi terhadap baseline di lokasi penelitian (\%)

\begin{tabular}{|c|c|c|c|c|c|c|c|c|}
\hline \multirow{2}{*}{$\begin{array}{l}\text { Periode } \\
\text { Proyeksi }\end{array}$} & \multicolumn{2}{|l|}{ Sumani } & \multicolumn{2}{|c|}{ Lubuk Sikarah } & \multicolumn{2}{|c|}{ Muara Panas } & \multicolumn{2}{|c|}{ Sukarami } \\
\hline & RCP4.5 & RCP8.5 & RCP4.5 & RCP8.5 & RCP4.5 & RCP8.5 & $\mathrm{RCP} 4.5$ & RCP8.5 \\
\hline Thn 2020 & 2,0 & 4,0 & 1,9 & 3,8 & 1,9 & 3,9 & 2,0 & 4,1 \\
\hline Thn 2030 & 5,1 & 6,1 & 5,0 & 5,9 & 5,0 & 5,9 & 5,2 & 6,1 \\
\hline Thn 2040 & 6,5 & 8,1 & 6,4 & 7,8 & 6,3 & 7,7 & 6,6 & 8,1 \\
\hline Rata-rata $2020-2040$ & 5,0 & 5,8 & 4,9 & 5,7 & 4,9 & 5,7 & 5,9 & 5,9 \\
\hline
\end{tabular}

Proyeksi kebutuhan air untuk tanaman padi di wilayah penelitian

Dampak perubahan iklim akan sangat singnifikan terjadi pada sektor pertanian karena sektor pertanian sangat bergantung pada kondisi iklim untuk pertumbuhan dan perkembangan tanaman. Kelebihan dan kekurangan air akibat perubahan curah hujan, perubahan tinggi-rendah nya suhu udara akan sangat mempengaruhi kebutuhan air untuk tanaman, yang apabila kebutuhannya tidak terpenuhi dapat mengakibatkan terganggunya hasil tanaman. Pada Tabel 6a-6d, merupakan tabulasi proyeksi kebutuhan air rata-rata pada tahun 2020-2040 untuk tanaman dan kebutuhan air untuk irigasi di lokasi penelitian. Pada tabel tersebut terlihat besaran nilai Eto, CWR, Eff.Rain dan Irr.Req untuk masing-masing periode musim tanam selama satu tahun, rentang waktu masing-masing periode musim tanam seperti yang tersaji pada Tabel 3.

Di Sumani, pada umumya curah hujan effektif yang terjadi cukup untuk memenuhi kebutuhan air untuk tanaman pada masing-masing periode musim tanam, baik pada skenario perubahan RCP4.5 maupun RCP8.5, kecuali untuk pada periode musim tanam yang ke dua (MT_2), dari bulan Mei-Agustus, curah hujan efektif mengalami defisit sebesar 83,1 mm dan 90,6 mm masing-masing pada skenario RCP4.5 dan RCP8.5 untuk memenuhi kebutuhan air pada periode musim tanam tersebut, seperti yang terlihat pada Tabel 5a.

Sementara di lokasi penelitian lainnya: Lubuk Sikarah, Muara Panas, dan Sukarami pada umumya curah hujan effektif yang terjadi cukup untuk memenuhi kebutuhan air untuk tanaman pada masing-masing periode musim tanam, baik pada skenario perubahan RCP4.5 maupun RCP8.5. Pada periode musim tanam yang ke dua (MT_2), yang dimulai dari bulan Mei hingga Agustus, curah hujan efektif sama dengan kebutuhan air untuk tanaman, sehingga tidak diperlukan penambahan air untuk memenuhi kebutuhan air untuk tanaman dari irigasi, (kebutuhan air irigasi $=0,0 \mathrm{~mm}$ ) seperti yang terlihat pada Tabel $5 \mathrm{~b}-5 \mathrm{~d}$. 
Simulasi Kebutuhan Air Untuk tanaman Padi Pada Skenario...(Sugeng Nugroho, dkk)

Tabel 5a Proyeksi kebutuhan air untuk tanaman dan irigasi di Sumani

\begin{tabular}{|c|c|c|c|c|c|c|c|c|}
\hline \multirow{2}{*}{$\begin{array}{c}\text { Periode } \\
\text { Musim } \\
\text { Tanam } \\
\text { (MT) }\end{array}$} & \multicolumn{2}{|c|}{$\begin{array}{c}\text { Potensial } \\
\text { Evapotranspirasi (ETo, } \\
\mathrm{mm} / \mathrm{musim})\end{array}$} & \multicolumn{2}{|c|}{$\begin{array}{l}\text { Kebutuhan Air untuk } \\
\text { Tanaman (CWR, } \\
\text { mm/musim) }\end{array}$} & \multicolumn{2}{|c|}{$\begin{array}{l}\text { Curah Hujan Efektif } \\
\text { (Eff.Rain, mm/musim) }\end{array}$} & \multicolumn{2}{|c|}{$\begin{array}{l}\text { Kebutuhan Air Irigasi } \\
\text { (Irr.Req, mm/musim) }\end{array}$} \\
\hline & RCP4.5 & RCP8.5 & RCP4.5 & RCP8.5 & RCP4.5 & RCP8.5 & RCP4.5 & RCP8.5 \\
\hline MT_1 & 577,8 & 585,9 & 652,9 & 662,1 & 885,3 & 881,6 & 0,0 & 0,0 \\
\hline MT_2 & 551,7 & 559,8 & 628,2 & 637,5 & 545,1 & 546,9 & 83,1 & 90,6 \\
\hline MT_3 & 591,7 & 599,1 & 680,4 & 682,5 & 1053,8 & 1032,9 & 0,0 & 0,0 \\
\hline
\end{tabular}

Tabel 5b Proyeksi kebutuhan air untuk tanaman dan irigasi di Lubuk Sikarah

\begin{tabular}{|c|c|c|c|c|c|c|c|c|}
\hline \multirow{2}{*}{$\begin{array}{l}\text { Periode } \\
\text { Musim } \\
\text { Tanam } \\
\text { (MT) }\end{array}$} & \multicolumn{2}{|c|}{$\begin{array}{c}\text { Potensial } \\
\text { Evapotranspirasi (ETo, } \\
\mathrm{mm} / \text { musim) }\end{array}$} & \multicolumn{2}{|c|}{$\begin{array}{l}\text { Kebutuhan Air untuk } \\
\text { Tanaman (CWR, } \\
\text { mm/musim) }\end{array}$} & \multicolumn{2}{|c|}{$\begin{array}{l}\text { Curah Hujan Efektif } \\
\qquad(\mathrm{mm} / \mathrm{musim})\end{array}$} & \multicolumn{2}{|c|}{$\begin{array}{l}\text { Kebutuhan Air Irigasi } \\
\text { (Irr.Req, mm/musim) }\end{array}$} \\
\hline & RCP4.5 & $\mathrm{RCP} 8.5$ & RCP4.5 & RCP8.5 & RCP4.5 & RCP8.5 & RCP4.5 & RCP8.5 \\
\hline MT_1 & 539,1 & 482,1 & 609,2 & 544,8 & 971,5 & 966,5 & 0,0 & 0,0 \\
\hline MT_2 & 513,3 & 516,9 & 584,5 & 588,6 & 616,3 & 616,3 & 0,0 & 0,0 \\
\hline MT_3 & 559,2 & 561,6 & 637,0 & 639,8 & 1184,7 & 1158,9 & 0,0 & 0,0 \\
\hline
\end{tabular}

Tabel 5c Proyeksi kebutuhan air untuk tanaman dan irigasi di Muara Panas

\begin{tabular}{|c|c|c|c|c|c|c|c|c|}
\hline \multirow{2}{*}{$\begin{array}{l}\text { Periode } \\
\text { Musim } \\
\text { Tanam } \\
\text { (MT) }\end{array}$} & \multicolumn{2}{|c|}{$\begin{array}{l}\text { Potensial } \\
\text { Evapotranspirasi (ETo, } \\
\mathrm{mm} / \text { musim) }\end{array}$} & \multicolumn{2}{|c|}{$\begin{array}{l}\text { Kebutuhan Air untuk } \\
\text { Tanaman (CWR, } \\
\text { mm/musim) }\end{array}$} & \multicolumn{2}{|c|}{$\begin{array}{l}\text { Curah Hujan Efektif } \\
\text { (mm/musim) }\end{array}$} & \multicolumn{2}{|c|}{$\begin{array}{l}\text { Kebutuhan Air Irigasi } \\
\text { (Irr.Req, mm/musim) }\end{array}$} \\
\hline & RCP4.5 & RCP8.5 & RCP4.5 & RCP8.5 & RCP4.5 & RCP8.5 & RCP4.5 & RCP8.5 \\
\hline MT_1 & 539,7 & 542,7 & 609,9 & 613,3 & 971,5 & 966,5 & 0,0 & 0,0 \\
\hline MT_2 & 513,3 & 516,9 & 584,5 & 588,6 & 616,3 & 616,3 & 0,0 & 0,0 \\
\hline MT_3 & 559,5 & 516,9 & 637,4 & 640,1 & 1184,7 & 1158,9 & 0,0 & 0,0 \\
\hline
\end{tabular}

Tabel 5d Proyeksi kebutuhan air untuk tanaman dan irigasi di Sukarami

\begin{tabular}{|c|c|c|c|c|c|c|c|c|}
\hline \multirow{2}{*}{$\begin{array}{c}\text { Periode } \\
\text { Musim } \\
\text { Tanam } \\
\text { (MT) }\end{array}$} & \multicolumn{2}{|c|}{$\begin{array}{c}\text { Potensial } \\
\text { Evapotranspirasi (ETo, } \\
\mathrm{mm} / \text { musim) }\end{array}$} & \multicolumn{2}{|c|}{$\begin{array}{c}\text { Kebutuhan Air untuk } \\
\text { Tanaman (CWR, } \\
\text { mm/musim) }\end{array}$} & \multicolumn{2}{|c|}{$\begin{array}{l}\text { Curah Hujan Efektif } \\
\text { (mm/musim) }\end{array}$} & \multicolumn{2}{|c|}{$\begin{array}{l}\text { Kebutuhan Air Irigasi } \\
\text { (Irr.Req, mm/musim) }\end{array}$} \\
\hline & RCP4.5 & RCP8.5 & RCP4.5 & RCP8.5 & RCP4.5 & RCP8.5 & RCP4.5 & RCP8.5 \\
\hline MT_1 & 546,6 & 549,0 & 617,7 & 620,4 & 971,5 & 966,5 & 0,0 & 0,0 \\
\hline MT_2 & 518,7 & 522,0 & 590,7 & 594,4 & 616,3 & 616,3 & 0,0 & 0,0 \\
\hline MT_3 & 566,1 & 568,8 & 644,9 & 648,0 & 1184,7 & 1158,9 & 0,0 & 0,0 \\
\hline
\end{tabular}


Jurnal Sumber Daya Air Vol. 15 No 1, Mei 2019: 15 - 26

Tabel 6a Perbandingan proyeksi kebutuhan air tanaman dan irigasi terhadap baseline di Sumani (\%)

\begin{tabular}{|c|c|c|c|c|c|c|c|c|}
\hline \multirow{2}{*}{$\begin{array}{l}\text { Periode } \\
\text { Musim } \\
\text { Tanam } \\
\text { (MT) }\end{array}$} & \multicolumn{2}{|c|}{$\begin{array}{c}\text { Potensial } \\
\text { Evapotranspirasi (ETo, } \\
\mathrm{mm} / \text { musim) }\end{array}$} & \multicolumn{2}{|c|}{$\begin{array}{l}\text { Kebutuhan Air untuk } \\
\text { Tanaman (CWR, } \\
\text { mm/musim) }\end{array}$} & \multicolumn{2}{|c|}{$\begin{array}{l}\text { Curah Hujan Efektif } \\
\text { (mm/musim) }\end{array}$} & \multicolumn{2}{|c|}{$\begin{array}{l}\text { Kebutuhan Air Irigasi } \\
\text { (Irr.Req, mm/musim) }\end{array}$} \\
\hline & RCP4.5 & RCP8.5 & RCP4.5 & RCP8.5 & $\mathrm{RCP} 4.5$ & RCP8.5 & RCP4.5 & RCP8.5 \\
\hline MT_1 & 1,9 & 3,7 & 1,9 & 3,7 & 7,3 & 6,2 & 0,0 & 0,0 \\
\hline MT_2 & 1,5 & 3,2 & 1,5 & 3,2 & 4,7 & 6,8 & $-15,7$ & $-14,6$ \\
\hline MT_3 & 2,7 & 2,7 & 2,7 & 2,7 & 7,8 & 6,1 & 0,0 & 0,0 \\
\hline
\end{tabular}

Tabel 6b Perbandingan proyeksi kebutuhan air tanaman dan irigasi terhadap baseline di Lubuk Sikarah (\%)

\begin{tabular}{|c|c|c|c|c|c|c|c|c|}
\hline \multirow{2}{*}{$\begin{array}{c}\text { Periode } \\
\text { Musim } \\
\text { Tanam } \\
\text { (MT) }\end{array}$} & \multicolumn{2}{|c|}{$\begin{array}{c}\text { Potensial } \\
\text { Evapotranspirasi (ETo, } \\
\mathrm{mm} / \text { musim) }\end{array}$} & \multicolumn{2}{|c|}{$\begin{array}{c}\text { Kebutuhan Air untuk } \\
\text { Tanaman (CWR, } \\
\text { mm/musim) }\end{array}$} & \multicolumn{2}{|c|}{$\begin{array}{l}\text { Curah Hujan Efektif } \\
\text { (mm/musim) }\end{array}$} & \multicolumn{2}{|c|}{$\begin{array}{l}\text { Kebutuhan Air Irigasi } \\
\text { (Irr.Req, mm/musim) }\end{array}$} \\
\hline & RCP4.5 & RCP8.5 & RCP4.5 & RCP8.5 & RCP4.5 & RCP8.5 & RCP4.5 & RCP8.5 \\
\hline MT_1 & 2,0 & 8,6 & 2,0 & 8,5 & 7,2 & 6,1 & --- & --- \\
\hline MT_2 & 2,0 & 2,3 & 2,0 & 2,3 & 4,6 & 6,3 & --- & --- \\
\hline MT_3 & 2,2 & 2,5 & 2,2 & 2,5 & 7,6 & 5,7 & --- & --- \\
\hline
\end{tabular}

Tabel 6c Perbandingan proyeksi kebutuhan air tanaman dan irigasi terhadap baseline di Muara Panas (\%)

\begin{tabular}{|c|c|c|c|c|c|c|c|c|}
\hline \multirow{2}{*}{$\begin{array}{c}\text { Periode } \\
\text { Musim } \\
\text { Tanam } \\
\text { (MT) }\end{array}$} & \multicolumn{2}{|c|}{$\begin{array}{c}\text { Potensial } \\
\text { Evapotranspirasi (ETo, } \\
\mathrm{mm} / \text { musim) }\end{array}$} & \multicolumn{2}{|c|}{$\begin{array}{l}\text { Kebutuhan Air untuk } \\
\text { Tanaman (CWR, } \\
\text { mm/musim) }\end{array}$} & \multicolumn{2}{|c|}{$\begin{array}{l}\text { Curah Hujan Efektif } \\
\text { (mm/musim) }\end{array}$} & \multicolumn{2}{|c|}{$\begin{array}{l}\text { Kebutuhan Air Irigasi } \\
\text { (Irr.Req, } \mathrm{mm} / \text { musim) }\end{array}$} \\
\hline & RCP4.5 & RCP8.5 & RCP4.5 & RCP8.5 & RCP4.5 & RCP8.5 & RCP4.5 & RCP8.5 \\
\hline MT_1 & 2,2 & 2,1 & 2,2 & 2,1 & 7,2 & 6,1 & --- & --- \\
\hline MT_2 & 2,0 & 2,3 & 2,0 & 2,3 & 4,6 & 6,3 & --- & --- \\
\hline MT_3 & 2,2 & 2,3 & 2,2 & 2,3 & 7,6 & 5,7 & --- & --- \\
\hline
\end{tabular}

Tabel 6d Perbandingan proyeksi kebutuhan air tanaman dan irigasi terhadap baseline di Sukarami (\%)

\begin{tabular}{|c|c|c|c|c|c|c|c|c|}
\hline \multirow{2}{*}{$\begin{array}{c}\text { Periode } \\
\text { Musim } \\
\text { Tanam } \\
\text { (MT) }\end{array}$} & \multicolumn{2}{|c|}{$\begin{array}{c}\text { Potensial } \\
\text { Evapotranspirasi (ETo, } \\
\mathrm{mm} / \text { musim) }\end{array}$} & \multicolumn{2}{|c|}{$\begin{array}{c}\text { Kebutuhan Air untuk } \\
\text { Tanaman (CWR, } \\
\text { mm/musim) }\end{array}$} & \multicolumn{2}{|c|}{$\begin{array}{l}\text { Curah Hujan Efektif } \\
\text { (mm/musim) }\end{array}$} & \multicolumn{2}{|c|}{$\begin{array}{l}\text { Kebutuhan Air Irigasi } \\
\text { (Irr.Req, } \mathrm{mm} / \mathrm{musim} \text { ) }\end{array}$} \\
\hline & RCP4.5 & RCP8.5 & RCP4.5 & RCP8.5 & RCP4.5 & RCP8.5 & RCP4.5 & RCP8.5 \\
\hline MT_1 & 2,2 & 2,6 & 2,2 & 2,6 & 7,2 & 6,1 & --- & --- \\
\hline MT_2 & 0,8 & 2,2 & 0,8 & 2,2 & 4,6 & 6,3 & --- & --- \\
\hline MT_3 & 2,1 & 2,4 & 2,1 & 2,4 & 7,6 & 5,7 & --- & --- \\
\hline
\end{tabular}

1) Perbandingan proyeksi kebutuhan air untuk tanaman padi

Perbandingan proyeksi kebutuhan air untuk tanaman padi dengan kondisi baseline di lokasi penelitian Sumani, semua parameter kebutuhan air untuk tanaman mengalami kenaikan, kecuali kebutuhan air untuk irigasi yang mengalami penurunan pada MT_2 sebesar $\quad-15,7 \%$ dan $14,6 \%$ masing-masing pada skenario RCP4.5 dan RCP8.5, seperti yang tersaji pada Tabel 6 a.

Sementara perbandingan kebutuhan air untuk tanaman padi dengan kondisi baseline di lokasi penelitian Lubuk Sikarah, Muara Panas dan 
Sukarmi seperti tersaji pada Tabel $6 b-6 d$, semua parameter kebutuhan air untuk tanama bernilai positif (mengalami kenaikan). Pada lokasi ini nilai curah hujan efektif nya lebih besar dibandingkan kebutuhan air untuk tanaman, sehingga tidak diperlukan penambahan air untuk memenuhi kebutuhan air tanama dari irigasi baik pada skenario RCP4.5 dan RCP8.5

\section{KESIMPULAN}

Dari hasil analisis dan pembahasan dapat disimpulkan bahwa: koreksi terhadap data model perubahan iklim perlu dilakukan, sehingga didapatkan data model yang mendekati data observasinya. Model koreksi bias CDFDM terbukti dapat membuat data model mendekati pola dan variasi data observasinya, khususnya untuk data suhu udara. Hasil proyeksi unsur iklim di lokasi penelitian menunjukan pada umumnya mengalami peningkatan. Peningkatan terbesar dialami curah hujan hingga $47,5 \%$ pada tahun 2040 jika iklim berubah dengan skenario RCP8.5 dan rata-rata mengalami peningkatan antara $18-20 \%$ pada tahun $2020-2040$, baik pada scenario RCP4.5 dan RCP8.5. Suhu udara akan mengalami peningkatan antara $4-6 \%$ pada tahun 2020-2040 pada scenario RCP4.5 dan RCP8.5. Sedangkan peningkatan suhu udara terbesar per dekade terbesar sekitar $8.1 \%$ pada tahun 2040 pada scenario RCP8.5.

Proyeksi kebutuhan air untuk tanaman secara umum mengalami peningkatan seiring dengan semakin tinggi nya proyeksi curah hujan dan suhu udara, kecuali untuk lokasi penelitian Sumani, yang mengalami defisit kebutuhan curah hujannya sehingga diperlukan air irigasi, pada musim tanam bulan Mei-Agustus.

\section{UCAPAN TERIMA KASIH}

Penulis berterimakasih kepada semua pihak yang telah mendukung pembuatan artikel ini. Ucapan terimakasih yang sangat spesial kepada dua reviewer yang telah memberikan saran dan masukan untuk kesempurnaan artikel ini.

\section{DAFTAR PUSTAKA}

Badan Pusat Statistik Kabupaten Solok. (2016). Kabupaten Solok Dalam Angka Tahun 2016. BPS Kabupaten Solok.

Badan Pusat Statistik Kota Solok. (2016). Kota Solok Dalam Angka Tahun 2016. BPS Kota Solok.
Clarke, D. (1998). CropWat for Windows : User Guide. University of Southtampton.

Doria, R.O. (2010). Impact of Climate Change on Crop Water Requirements in Eastern Canada.Ph.D (Tidak dipublikasi) Thesis Departement of Bioresource Engineering, McGill University, Montreal, Quebec, Canada.

Ekaputa, E.G. (2007). Dinamika Hasil Air Daerah Aliran Sungai Ditinjau Dari Keberlanjutan Sumberdaya Air Untuk Pertanian. (Tidak dipublikasi) Disertasi Sekolah Pascasarjana Universitas Gadjah Mada, Yogyakarta.

Ghahreman, N., M. Tabatabaei \& Babaeian. (2015). Investigation of Uncertainty in the IPCC AR5 Precipitation and Temperature Projection over Iran under RCP Scenarios. Poster on COP21CMP11.

lizumi , Toshichika, M. Nishimori, K. Dairaku, S.A. Adachi, \& M. Yokozawa. (2011). Evaluation and intercomparison of downscaled daily precipitation indices over Japan in presentday climate: Strengths and weaknesses of dynamical and bias correctiontype statistical downscaling methods. Journal of Geophysical Research, 116. DOI:10.1029/2010JD014513.

lizumi, Toshichika, H. Takikawa, Y. Hirabayashi, N. Hanasaki, \& M. Nishimori. (2017). Contributions of different bias-correction methods and reference meteorological forcing data sets to uncertainty in projected temperature and precipitation extremes. J. Geophys. Res. Atmos., 122, 7800-7819, doi:10.1002/2017JD026613.

Kuo, Feng-Seng, Bor-Jan Lin \& Horng-Je Shieh, (2001). CropWat Model to Evaluaate Water Requirements in Taiwan. International Commission on Irrigation and Drainage $1^{\text {st }}$ Asian Regional Confenrence, Seoul, South Korea.

Mizwar, Z. (2012). Aplikasi Model Hidrologi Dalam Penentuan Sistem Panen Hujan Dan Aliran Permukaan Daerah Tangkapan Air Singkarak. (Tidak dipublikasi) Disertasi Sekolah Pascasarjana Institut Pertanian Bogor, Bogor.

Monteith, J.L. (1965). Evaporation and environment in The State and movement of water in living organism. In $19^{\text {th }}$ Symp. Soc. Exptl. Biol. Pp. 205-234.

Muharsyah, R. (2018). Koreksi Bias Hasil Proyeksi MIROC5 Keluaran WRF dengan Metode CDFDM. Buletin Megasains, 9. 
Nugroho, S. (2010). Validasi Model AGNPS (Agricultural Non Point Source) Untuk Menentukan Sedimen dan Nutrien di Sub-Sub DAS Sumani Kabupaten Solok. (Tidak dipublikasi)Thesis Program Studi IImu Lingkungan, Program Pascasarjana, Universitas Negeri Padang, Padang.

Nugroho, S., R. Febriamansyah, R. Muharsyah. (2017). Penilaian Ketidakpastian Data Model Perubahan Iklim dengan Metode CDFDM di Wilayah Sumatera Barat. Jurnal Solum 14(2): 51-72. ISSN 1829-7994.

Saidi, A. (1995). Faktor-Faktor yang Memepengaruhi Aliran Permukaan dan Sedimentasi serta Dampaknya Terhadap Degradasi Lahan di Sub-Sub DAS Sumani, Solok Sumatera Barat. (Tidak dipublikasi) Disertasi Program Pascasarjana Universitas Padjadjaran, Bandung.

Suprapto, M. (2012). Konsep Pengelolaan Sumber Daya Air Berkelanjutan. Jurnal Teknik Sipil, 12(1):61-65.

Surendran, U. C.M. Sushanth, G. Mammen \& E.J. Joseph. (2017). FAO-CropWat Model-Based Estimation of Crop Water Need and Appraisal of Water Resource Management: Pilot Study for Kollam District-Humid Tropical Region of Kerala, India. Current Science, 112(1):76-86.
Tonouchi \& Chiba. (2015). CDFDM, Metode Koreksi Bias. Materi Pelatihan Perubahan Iklim, Kerjasama BMKG-JICA, Jakarta.

Weyant, John, C. Azar, M. Kainuma, J. Kejun, N. Nakicenovic, P.R. Shukla, E. L., Rovere and G. Yohe. (2009). Report of 2.6 Versus 2.9 Watts/m2 RCPP Evaluation Panel. Geneve, Switzerland: IPCC Secretariat. 81 pages.

Withanachchi, S.S., S.Kopke, Chandana R. Withanachchi, R. Pathiranage and A. Ploeger, (2014). Water resource management in dry zonal paddy cultivation in Mahaweli river basin, Sri Langka: An analysis of spasial and temporal climate change impacts and traditional knowledge. Climate, 2: 329-354. DOI 10.3390/cli2040392

Zhang, Y. Qinglong, Y. Changchun, C. and Jing, G., 2016. Impacts of climate change on streamflows under RCP scenarios: A case study in Xin River Basin, China. Journal Atmospheric Research, 178-179:521-534, http://dx.doi.org/10.1016/i.atmossres.2016.04 $\underline{6.018 .}$. 